\title{
The Significance of Introducing Culture in EFL Instruction
}

\author{
Noor Malihah \\ English Department of Educational Faculty \\ State Islamic Studies Institute (STAIN) Salatiga \\ J. Tentara Pelajar no. 2 Salatiga, Central Java, Indonesia
}

\begin{abstract}
EFL students many times made mistakes in using the English expressions and led to misinterpretations or even acceptable message of their utterances. This is due to their lack of cultural awareness or their understanding towards L2 culture. Therefore, EFL teachers should think of how to give position to the L1 and L2 culture in their teaching and learning process of EFL instructions.To solve the problems, there are some approaches used to introduce the target language culture, by knowing the obstacles that the learners frequently made.
\end{abstract}

Keywords: EFL, Cultural, Awareness, Approaches, Obstacles

\begin{abstract}
Abstrak
Pembelajar bahasa Inggris sebagai bahasa asing berkali-kali melakukan kesalahan dalam menggunakan ungkapan-ungkapan bahasa Inggris sehingga menyebabkan salah tafsir atau bahkan pesan yang diterima pada ujaran mereka . Hal ini disebabkan kurangnya kesadaran budaya atau pemahaman mereka terhadap budaya L2 . Oleh karena itu, guru bahasa inggris perlu memikirkan bagaimana memberikan porsi pengenalan budaya L1 dan L2 dalam proses belajar mengajar bahasa inggris sebagai bahasa asing. Untuk memecahkan masalah tersebut, ada beberapa pendekatan yang digunakan untuk memperkenalkan budaya bahasa target, dengan mengenali kendala yang sering ditemui oleh peserta didik.
\end{abstract}

Kata Kunci: EFL, Budaya, Kesadaran, Pendekatan, Hambatan

REGISTER, VOL. 1, N0. 1, 2008 


\section{Introduction}

As everybody knows, English is very popular language spoken and learned by many people throughout the world at recent time. This is due to a certain demand, which is today needed in facing the free trade in the globalization era where everything, included any information can be adopted easily, and English is as the international language, which is acknowledged both conventionally and administered. Plunging into the opened-Era, what is so called for globalization era, involves man aspects of life such as economic, politic, social, academic, and so on.

Culture has become an increasingly important component of English language teaching in recent times. There are a number of reasons for this, due to the wide use of English all over the world by multicultural communities. It therefore is necessary to examine the use of English in Indonesia and the teaching of culture.

Many times, our students use inappropriate English utterances while having a conversation in English due to their lack of cultural awareness about the target language. It disturbs the goals of communication, as the message of the utterance will be blur since it probably creates misinterpretations or unacceptable communication. Let us consider the following example:

1). $\quad \mathrm{X}$ : Thank you

Y: same-same

2). $\quad \mathrm{X}$ : When will you come to her house?

Y. In the morning day

3). X: Where are they?

Y: Walking-walking

4). $\quad \mathrm{X}$ : What is your father?

REGISTER, VOL. 1, N0. 1, 2008 
Y: My father is a human

The above utterances show indifferent responds uttered by the NonNative Speakers, as EFL learners. It can be seen from utterance 1), where the respond of thank you, is same-same, instead of you're welcome or other proper expression, which is actually the derivation of Indonesian culture; when someone terima kasih 'thank you' the answer will be sama-sama 'same-same'. Similarly, the expression in no 2) also the derivation of L1 context where in the morning day is word-to-word translation of pada pagi hari which should be in the morning. So does in the utterance no 3), where the form of walking-walking is the word to word translation of jalan-jalan 'walk around'. In no 4), the answer stated by $\mathrm{Y}$ is improper to the question given by $\mathrm{X}$ due to the English context. However, since $\mathrm{Y}$ is lack of understanding English culture, the answer is derived from the Indonesian context where the question means Bapakmu itu apa?, 'what is this (thing)?; and the answer expected is whether he is a man, a thing, or others. The speaker did not think that the question is actually to know his father job.

The other improper expressions resulted by lack of understanding culture of L2 are:

5). $\quad \mathrm{X}$ : Are you married?

6). $\quad \mathrm{X}$ : How old are you?

7). $\quad \mathrm{X}$ : How much salary do you get to work in that company?

Questions in 5), 6), and 7) are forbidden in the English context instead those are given by an interviewer in job interview; however it is permissible in Indonesian culture, especially for the Javanese in order to break the ice for having conversation with new acquaintance.

8) Mbak Erica, Do you like to be in Indonesia?

REGISTER, VOL. 1, N0. 1, 2008 
The use of address form in the above sentence is acceptable in the Indonesian context; however, if it is applied in the real culture of English Native speakers, they probably get confused with such term. It is due to the different system of addressing.

Dealing with this case, therefore, it is very necessary for EFL teachers to think about how to introduce the culture of English in the real conversation. As everyone knows that teaching English in outside of English speaking countries leads to some difficulties in introducing the culture awareness, thus there should be a study on how these difficulties may be overcome and how we might approach the teaching of cultural awareness in a systematic way as applied to the Indonesian environment.

\section{Discussion}

\section{The language and culture in communication}

Whorfian (Wardaugh, 1992: 218) presents his hypotheses about language and culture: (1) the structure of a language determines the way in which the speakers of that language view the world,; (2) the culture of people finds reflection in the language they employ, because they value certain things and do them in a certain way, they come to use their language in ways that reflect what they value and what they do.; (3) there is little or no relationship between language and culture. In other side, Sapir acknowledged the close relationship between language and culture, maintaining that they were inextricably related so that it is impossible to understand or appreciate the one without knowledge of the other. Therefore, every language will reflect the values, beliefs, and assumptions of the culture it came from. Thus learning a language will also involve learning the culture the language expresses and consequently, our view of language teachingshould link between culture and language.

REGISTER, VOL. 1, N0. 1, 2008 
To be able to communicate well means that it is not merely to understand the syntax and range of _expression within a language. Hymes' (1972) definition of communicative competence, which underpins much of communicative language teaching, prompts the importance of understanding the socio-linguistic aspects of language. Communicative competence involves an understanding of the norms of social interaction of one sociocultural community, intercultural communicative competence entails an understanding of the differences in interactional norms between different speech communities and an ability to "reconcile or mediate between different modes present" (Byram and Fleming 1998, 12). Central to the notion of intercultural communicative competence is 'cultural awareness'. Cultural awareness involves an understanding not only of the culture of the language being studied but also of the learners' own culture. This view leads to a fact that it will be impossible to have successful communication without grasping the cultural awareness.

\section{The English teaching and use in the Indonesian culture}

English is a very popular language spoken and learned as well as used and taught in a diverse range of situations and cultures throughout the world, often far removed, in both distance and in beliefs and values, from the cultures of the original English speaking countries at present times. Krachu (1977) has illustrated different varieties of English outside of these original English-speaking countries such as Indian English and Nigerian English. Many of these contexts, such as Asia have very different beliefs, value systems, and educational doctrines to the traditional English speaking countries such as Great Britain and the United States. For the Indonesian people, English is as a foreign language, which is taught in schools often from the third years of schooling since it becomes the local content to be 
studied in formal schools. At present days, English competency is one of the requirements in government universities undergraduate and post-graduate degrees. Therefore the teaching of English provides chance to give variety of uses English in a variety of Indonesian contexts in ways removed from native speaker norms.

\section{Various cultures lead to difficulties in teaching language}

English teaching and use may occur in a wide variety of contexts in non-English speaking countries, which often do not involve English Native Speaker (NS). This raises the important question of what culture we should be addressing when teaching cultural awareness. If not all communication is taking place with English NS then it may not be relevant to teach English culture.

Contradictory to the Whorf Hypotheses, Alptekin and Alptekin (1984: 16) suggest that we should not be teaching English with reference to Englishspeaking countries' cultures but be independent from the cultural context instead referring only to the "International attitudes" English; as stated at the beginning of this paper, culture and language are inexorably linked and as such cannot be separated. Someother linguists prompt that (see Valdes, 1986, 1990, Byram 1991, Byram and Fleming 1998, Kramsch 1993) teaching English without teaching culture is impossible. Through conscious or unconscious process, it is unavoidable to transmit the culture of the language during the teaching learning process. Since the outside speaking English countries are so many, as well as the Indonesian, there will arise many difficulties in grasping the culture of the foreign language in the native language situation, which culture should be applied in teaching the language, the native language or the foreign language?

National characteristics vs. the foreign language characteristics

REGISTER, VOL. 1, N0. 1, 2008 
Some people attempt to identify their national characteristics for the purposes of comparing and contrasting cultures, leads to oversimplification and stereotypes of cultural characteristics. Such belief will reject the diversity of other cultures. This can create an unrealistic stereotyped view of English culture in learners, especially when learners compare the culture presented in TESOL materials with their own probably more balanced view of their own culture (Guest, 1990: 35). Their attitude towards English will influence much on the achievement in using the language. Therefore, it is important to distinct between generalizations and stereotypes. Stereotypes are fixed and are not open to change or modification with experience, whereas generalizations are flexible and change over time with our experiences (Clarke and Clarke 1990, 34) and thus can aid understanding. As Lado (1957 cited in Valdes 1986) notes, when comparing two cultures we must be very careful in the generalizations we make and be prepared to revise or change these generalizations as our understanding of another culture develops. This yields in the facts that the Indonesian learners will be exposed to encounter with English culture through Western media and brief encounters with tourists, which can easily lead to unrepresentative stereotypical impressions. The teachers can solve it by helping the learners through discussions and critical examinations of them in the classroom using the English media.

\section{How to teach culture?}

Referring to the theme of this writing that language and culture are inseparable and that in teaching English we will also be transmitting the values of English culture, in agreement, Kramsch has pointed out that "language teachers are so much teachers of culture that culture has often become invisible to them."(1993: 48). Therefore, culture should be best taught in all aspects of language such as grammar and vocabulary. A survey

REGISTER, VOL. 1, N0. 1, 2008 
by Timmis (2002), states that the majority of learners and teachers of English from a large range of countries expressed a desire to speak English according to native speaker norms, however the survey also demonstrated a wish to retain aspects of their own culture such as accent, especially amongst Asian students (Timmis 2002, 242). These surveys would seem to provide good evidence for teaching the culture of English speaking countries. However, they also suggest that not only English-speaking culture should be taught but also other cultures need to be examined. In particular, learners need to develop an awareness of their own and other cultures and this will be dealt with more fully in the examination of approaches to teaching culture.

Dunnet et. al. suggest six aspects of culture that learners and teachers should be familiar with. They are: (1) Languages cannot be translated wordfor-word...(2) The tone of a speaker's voice (the intonation pattern) carries meaning... (3) Each language-culture employs gestures and body movements which convey meaning...(4)...languages use different grammatical elements for describing all parts of the physical world. (5) All cultures have taboo topics...(6) In personal relationships, the terms for addressing people vary considerably among languages. (1986, 148-149). Teachers and learners should be aware of these features and be prepared to analyze both their own culture and the target culture according to such criteria.

Languages cannot be translated word for word.

As Dunnett et al. stress individual words have idiomatic uses and connotations that go beyond the individual word itself. If we take the English word 'serious' the list of connotations for a Indonesian are very different to the average native speaker. Whereas in English it can have positive, negative, or neutral connotations, the Indonesian connotations of 'hostess' (which can be translated in various ways e.g. 'nyonya rumah', 'wanita penghibur' or even

REGISTER, VOL. 1, N0. 1, 2008 
'PSK') are very different and usually associated with immoral woman. This is not a concept that is likely to explain in a simple dictionary style word-forword translation.

The intonation pattern carries meaning.

The Indonesian language is a tonal language and so the intonation patterns are very different to the English language. For Indonesian students, it is important that they recognize the importance of tonal patterns at the super segmental level in English as opposed to the individual syllable pattern for tones in Indonesian.

Languages and cultures use non-verbalcommunication that conveys meaning.

Although many gestures are similar in Indonesian and English such as nodding for affirmation many others are not shared. A good example of this is the ubiquitous 'Indonesian smile'. A smile given by some one will be interpreted in various ways such like happiness, acceptance, satire, annoyance, etc.

Languages use different grammatical elements for describing the physical world.

Indonesian and English grammar are very different in a number of areas such as subject use, tense and aspect, inflections and word order. These can at times cause communication problems at a semantic level. For instance, the Indonesian language contains no tense or aspect. This can make areas of English grammar such as past simple or present perfect and any accompanying temporal references difficult to grasp for Indonesian learners. Even when learners understand them, they may find them cumbersome and avoid using them (Svalberg and Chuchu 1998). The extent to which this may represent different approaches to viewing the physical world are debatable,

REGISTER, VOL. 1, N0. 1, 2008 
however it will be understandable for those who are familiar with both Indonesian and English culture that there is a different concept about time.

Cultures have taboo topics.

Many of the topic taboos of English and Indonesian culture are the same and certainly, Indonesian's rarely give offence, in my experience, to native English speakers in terms of topic choice. Nevertheless, there are a number of topics, which are perhaps a more acceptable choice of topic in Indonesian than in English. For the English speakers, talking about marital status, salary, religion, and age are taboo, meanwhile such topics are not taboo to the Indonesian speakers since they usually easy to move their conversation by asking the topics.

The terms for addressing people vary considerably among languages.

This is another area of considerable difference between English and Indonesian. Terms of address in Indonesia often refer to the age of the interlocutors. There is no equivalent for this in English, although Indonesian students often ask for age clarification when it is not given in English. For example when asked about my family, the Indonesian learners will ask whether the brother or sister is younger or older than the speaker, and therefore they need to know how the address their family members where at the same time comparing the addressing terms use in both languages. It is known that in Indonesia we know such term of 'mbak', 'mas', or 'dik' which reflect to the age of the intended person towards the family. It is not found in English terms. On the way around, there is no use of such first names in formal address rather than surnames. Native English speakers are often referred to as Mr. followed by their first name and no surname e.g. Mr. William.

REGISTER, VOL. 1, N0. 1, 2008 
Then it needs effort to achieve a full understanding of culture. If language and culture are inseparable then as learners acquire a new language they will also be acquiring a new culture. However, we cannot expect this culture to be the same as either the learners' native culture or the culture of the language they are studying. The learner will initially have a synthesis with their own culture, and in learning, a foreign language such as English may use it in ways that express meaning in their own culture. Nevertheless, as learners' understanding of a foreign language develops they may come to understand other values and meanings familiar to the foreign culture that are alien to their own culture. Yet their understanding of these values and meanings may still be different to that of the native speaker.

Due to this phenomenon, Kramsch suggests that there should be a 'third place' in foreign language learning that the learner must make for him/herself between their first cultures (C1) and the foreign language culture (C2). This 'third place' involves the language learner in an objective and subjective reflection of $\mathrm{C} 1$ and $\mathrm{C} 2$ from which they must choose their own meanings that best reflect their personal perspectives. Hence, this conception of culture emphasizes the importance of individual interpretations of culture rather than rigid stereotypical notions. If this process of acquiring culture and language is successful, learners should be able to use English in such a way as to communicate effectively with English NS and in a way that reflects their own local cultures and personal beliefs (see Kramsch and Sullivan 1996). In this way, learners of English will no longer be seen as trying to be pseudo-English NS but as speakers in their own right.

\section{The implementation in language teaching}

The importance of culture within English teaching in Indonesia develops well at present as well as the need for teachers and learners to be

REGISTER, VOL. 1, N0. 1, 2008 
aware of the complexity of culture. Since there are the various uses of English in Indonesia previously, it will be better that the Indonesian learners need to use English in multi-cultural contexts rather than with reference to only the English speech community, and teaching content needs to reflect this. Furthermore, teaching methodology itself needs to mediate between Indonesian and Western educational values, especially concerning communicative, learner-centered approaches to language teaching (see for example Williams 1992, Kajornboon 2000).

There are some aspects, which are important to pay attention to, they are (1) the teaching of culture should take place within the normal language classroom and not as a separate subject as has been traditionally the case in Indonesia. (2) Equally importantly, materials and content in EFL instruction should try to make learners aware of the cultural content of language learning and encourage Indonesian learners to compare English culture with their own. (3) These materials must also encourage learners to compare cultures and to take a critical perspective. Tomalin and Stempleski (1993) propose a range of tasks such as class discussions, research and role-plays using materials drawn from English speaking countries that promote discussions, comparisons and reflection on English culture and the learners own culture. (4) Teacher training for both the Native English Speaking Teacher (NEST) and non-NEST should equip them to deal with culture and cultural contrasts as they arise in English teaching. In the context of learning English in nonEnglish speaking countries, for the local non-NEST, knowledge of English culture and of their own culture would be necessary and some time spent in an English speaking country would be valuable.

REGISTER, VOL. 1, N0. 1, 2008 


\section{Conclusion}

If culture and language are interlinked and inseparable then we need to try to teach culture in some kind of systematic way, as we try to do with other aspects of language. However, there are problems in deciding what culture to teach, possibly creating cultural stereotypes, and ignoring the individual when teaching culture. Furthermore, in many foreign countries, such as Indonesia, English is often used as an international language rather than as a means of communicating with English speakers from English speaking countries, bringing into question the relevance of English speaking culture. Nevertheless, these difficulties do not mean that culture should be ignored or left to unconscious processes. Learners and teachers should be aware of the cultural aspects of communication and language and need to be able to interpret these on both national and individual levels. They should also be prepared to re-evaluate and re-assess their knowledge based on experience. Learners also need to be encouraged to view using a second language as a new cultural experience and not part of either their native culture or the TL culture. Communication in an L2 or FL takes place in a 'third place'. Teacher training, materials, and course content within Indonesia need to reflect such uses of English. English teachers in Indonesia should be familiar with both English and Indonesian culture and be able to take crosscultural perspectives. Moreover, materials should encourage learners to reflect on comparisons between cultures and to form their own perspective on them; through materials drawn from English cultures, cross-cultural materials involving outsiders' observations on English culture, and locally produced (Indonesian) English materials. Finally the teaching of culture should be integrated into normal English lessons and be a covert part of the lesson. The view of language learning presented above encourages learners to view

REGISTER, VOL. 1, N0. 1, 2008 
themselves as acquiring a new culture and one that enables them to take a cross-cultural perspective on their own and the TL culture.

\section{References}

Alptekin, C. and Alptekin, M. 1984.'The question of culture: EFL teaching in non-English speaking countries' ELT Journal 38/1:14-20

Baker.W. 2003. Should culture be an overt component of EFL instruction outside of English speaking countries? The Thai context. Asian EFL Journal 1/2007-12/2007. Retrieved fromhttp://www.asian-efljournal.com/EFL_sites_search.php

Byram, M. and Fleming, M. 1998.Language Learning in Intercultural Perspective. Cambridge: Cambridge University Press

Damnet, A. 2003. Acquisition of Intercultural Non-verbal competence: Examining the Discourse, The 23rd Thailand TESOL International Conference; January 23-25, 2003; Bangkok, Thailand

Dunnett, S., Dubin, F. and Lezberg, A. 1986.English Language Teaching from an Intercultural Perspective, in Valdes, J. Culture Bound, Cambridge: Cambridge University Press

Hymes, D. 1972.On communicative competence in Pride, J. and Holmes, J. (eds.), Sociolinguistics, Harmondsworth: Penguin, pp 269-293

Kachru, B.B. 1977.'The New Englishes and Old Models' English Teaching Forum 15/3:29-35

Kramsch, C. 1993.Context and Culture in Language Teaching, Oxford: Oxford University Press

Kramsch, C. and Sullivan, P. 1996. Appropriate pedagogy, ELT Journal 50/3: $199-212$

REGISTER, VOL. 1, N0. 1, 2008 
Lado, R. 1986.How to compare two cultures, in Valdes, J. Culture Bound, Cambridge: Cambridge University Press

Timmis, I. 2002.Native-speaker norms and International English: a classroom view, ELT Journal 56/3: 240-249

Tomalin, B. and Stempleski, S. 1993.Cultural Awareness, Oxford: Oxford University Press

Wardaugh. R. 1992. Introduction to Sociolinguistics. London: Blackwell

Publ.

REGISTER, VOL. 1, N0. 1, 2008 